UDC 327

DOI: $10.24045 / \mathrm{pp} .2017 .2 .5$

\title{
THE REGIONALIZATION PROCESSES IN THE CASE OF THE SHANGHAI COOPERATION ORGANIZATION
}

\author{
E. S. Taukebayeva \\ L. A. Baidibekova \\ A. B. Begim
}

\author{
Ph.D. assistant professor \\ $\mathrm{Mg}$. \\ $M g$. \\ South-Kazakhstan State University \\ named after M. Auezov \\ Shymkent, Kazakhstan
}

\begin{abstract}
Nowadays regionalization processes cover almost all countries of the world. There are a number of successful and effective projects in the developed parts of the world. The fragmented third world also tried to find a panacea for decision its economic and political problems by the way of interstate integration. These processes are inherent for Central Asia and neighbouring states too. One of their opportunities of regionalization's realization is the creation of the Shanghai Cooperation Organization (SCO) space, which has been formed as a structure of cooperation in the sphere of security, for quite some time now it has started to expand the economic component in the activity of this organization; this process is actively lobbied by China. The fate of the organization depends on extensiveness of these spheres and its possibility to persuade the states in its capacity to achieve success.
\end{abstract}

Keywords: regionalization; integration; Central Asia; Shanghai Cooperation Organization; Russia; China.

The concept "regionalization" is always correlated with the concept "globalization" and often is considered in its context. But the approaches of analysis of these two processes are different. Some people assert that regionalization is a component of globalization; the others regard it as an alternative.

Stanford Encyclopedia of Philosophy explains that "globalization refers to fundamental changes in the spatial and temporal contours of social existence, according to which the significance of space or territory undergoes shifts in the face of a no less dramatic acceleration in the temporal structure of crucial forms of human activity" [1].

We assume that globalization has led to the search for counterbalances and attempts of creation of geopolitical balance by means of regionalization of international relations. The modern world is not limited by real geo- graphical space, it has become multidimensional. The states have to face many challenges, including the transformation of perceptions of a state sovereignty. The winners will be those, who are most effectively capable to use geopolitical, geo-economic and civilization code at the present place and social time for national security interests and for acceleration of financial, industrial and trade capital's turnover.

With the collapse of the USSR and gaining the independence by new sovereign states, the ex-Soviet Union's republics started to learn the laws and rules of world economic relations, experience pluses and minuses of economic ties, and therefore, having investigated the experience of other countries, to elaborate legal and economic mechanisms of adaptation to world economic processes, in order to defend their interests in the 
treaties with foreign states competently, to gain respect and strive for cooperation.

Regional unions of various countries are becoming necessary condition for improvement of their role in world economy, strengthening of national competitiveness and counteraction to regional security threats. More active influence on regionalization processes is demonstrated by China and Russia, especially in the frames of the Shanghai Cooperation Organization (SCO), where they cooperate equally with Kazakhstan, Kyrgyzstan, Uzbekistan and Tajikistan.

The SCO, originally called the Shanghai Five, was formed in 1996, and got its nowadays name in 2001, when Uzbekistan has joined its structure. The organization has ambitious intentions as its main goals are "strengthening mutual confidence and goodneighborly relations among the member countries; promoting effective cooperation in politics, trade and economy, science and technology, culture as well as education, energy, transportation, tourism, environmental protection and other fields; making joint efforts to maintain and ensure peace, security and stability in the region, moving towards the establishment of a new, democratic, just and rational political and economic international order..." [2]. The creation and enlargement of this organization has put into circulation a new concept "the SCO space", its appearance is a consequence of serious geopolitical, geo-economic and geo-strategic changes, connected with the collapse of the USSR. Then there was a lap of energetic factor with involving of ex-Soviet republics into the orbit of world politics, which led to the emergence of military forces of the USA and NATO in the region, activization of such actors as the EU, India, Japan etc. and consequently the response from China and Russia. Taking into account the abovementioned we'll consider first the meaning of the SCO for Chinese and Russian regionalization processes, then its impact on the Central Asian members, problems and perspectives of the integrating region.

The SCO space is a region, where two great powers China and Russia and significant in their location Central Asian members are trying to adhere to a multilateral policy. They are cooperating in order to create a basis for successful forming of multipolar system of world order. But both China and Russia have different perceptions of the SCO's significance for their regionalization. For example, Kerr D. explains that "China-centred strategic regionalism is organized through the $\mathrm{SCO}$; the Russia-centred system is the CIS and its military and economic structures, the Collective Security Treaty Organisation (CSTO) and the Euro-Asian Economic Community (EurAsEC)" [3].

The activity within the SCO for China is the continuation of their "Good Neighbourhood Policy", which has come from the understanding that "the better way is to have a partnership with all neighbours through certain regional-multilateral mechanisms" [4]. One of the main spheres of cooperation of China with Central Asian countries is economics. At this particular sphere the region's significance for China and its capability to realize its strategic aims are revealed most saliently. Total investment cost of Chinese enterprises into five Central Asian states of the SCO exceeded 9 billion dollars $\$$. The main investments are directed into oil and gas branch, transport, telecommunications, electric power industry, chemical industry, construction materials, contract projects, agriculture and processing of agriculture production [5].

The Chinese administration correlates its economic tasks with military-strategic ones. The most important strategic task is the creation of "security belt" along perimeter of its borders via liquidation or at least minimization of such threats as separatism, Islamic extremism, Turk nationalism in Xinjiang, and international terrorism inside Central Asia and around it. Chinese specialists assume that

Paradigmata poznóní. 2. 20 I7 
Central Asia should become a reliable strategic rear of China as the situation in this region directly influence on the security of China itself [6]. In perspective China probably considers the possibility of conditioning for its own military-strategic presence in the region that is why it is not interested in dominance of any other international power, except the SCO, in Central Asia. It is confirmed by the activization of China's armed forces in trainings of the SCO and rendering of military technical assistance of China to its strategic partners in this organization in the last years. China is interested in strengthening its geopolitical positions in the region. It is made not only in order to struggle with separatists of Xinjiang, but also as a response to the trials of the USA and Western countries' fastening in Central Asia and direct striving of China to lay strong basis for its energetic and even national security as a whole. Thus, China not only provides its access to the energy carriers of the region, but also strengthens strategic interaction with Central Asian countries, transforming them into stable foreign political and reliable economic partners.

The SCO for China and its other members is a platform, which grants possibility to participate in the regional geopolitics as equals. This organization is necessary for China, because by means of the SCO, China can calm Russia regarding its activity in development of its relationships with the Central Asian countries, as though the SCO is legitimizing the efforts of China in the struggle for the leadership in Asia.

Any scenario, which can entail the destabilization of the situation in Central Asia, whether it is economic softening, extremely sensible during the world crisis, or extremism's fits, initiated by various reasons or forces, may have rather undesirable consequences for Russia. The Russian scientists, for example A. Klimenko, as D. Kerr, considers that Russia doesn't pay much attention and resources in contrast with China to the perspectives of development of the SCO [6]. In its cooperation with Central Asian countries it first relies on such structures as CIS, CSTO and EurAsEC. During approximately two centuries they lived in one country, the development of Central Asian states was oriented on Russia and was formed by it. These facts reflected on the post-disintegration processes, where Russia and Central Asian countries are participants of common military-political and economical structures.

As for the SCO, Russia has relatively less influence in it, but for Russia it would be wrong to diminish the significance of it. It plays a unique role in regionalization processes as it provides dialogue with China and other big regional actors regarding Central Asia. The Kazakhstani scientist N. Kirabaev asserts that through this organisation "Russia obtains an additional lever for soft and polite limiting the entrance of China into Central Asia" [7]. In addition, Russia solves a number of other problems; among them there are stabilizing cooperation with the regional countries and moving aside the U.S. from Central Asia. These perceptions are inherent to the Western scientists. For example, Mark N. Katz asserts, that "Moscow has attempted to make use of the organization to resist efforts at democratization emanating from inside and outside the member states, to limit American and other Western influence in Central Asia, and to promote Russian foreign policy goals generally" [8]. Everyone understands that the attempts to transform the organization into anti-Western or antiAmerican bloc will inevitably fail, because it contradicts to original interests of memberstates, which are interested in cooperation with West in many directions. The activity of organization doesn't deny or belittle the mechanisms of cooperation, which have been worked out by member-states with other countries or groups of countries. If the SCO 
wants to have effective regionalization, its task is to create additional spheres of cooperation, which haven't existed earlier or haven't been possible out of its frames.

After the collapse of the USSR and gaining the independence the Central Asian states got an opportunity to choose their own way of development and became independent actors of international relations. They began to play a role, defined by their midland position, absence of exits to world sea lanes, existence of potentially large sources of strategically important mineral resources, economic and demographical potential, character of interactions with other states, first of all with neighbours, their participation in regional and global international organizations. Besides the regionalization processes in Central Asia are conditioned by the existence of crisis zones along the perimeter of boundaries, by the perspective communication transit character of territories of the region's states.

All these factors together create a complicated enough geopolitical situation in the region, and also causes the pragmatic interest to the countries of Central Asia from the nearest neighbours and world powers. Having understood that Asia as such does not exist as a political, economic, or military actor; instead there are many Asians and this multiplicity is not converging but more diverging, the Central Asian states try to adhere to more perspective projects, one of which is the SCO.

The SCO is a structure, where Central Asian countries try to balance between Russia and China, two natural neighbours, which are nuclear powers. It is a real chance of Central Asian states to be a part of a power center, which could become one of the most important elements of a multipolar world.

Nowadays if we examine the modern state of the SCO, we see some stagnation of it. Some of the members are just trying to ensure their own nationalist interests, not always shared by partners. Disagreements be- tween Central Asian states are still remaining. The partnership is accompanied by certain competitiveness in the SCO. It is true, that such situation is inherent to almost all interstate organization: in the $\mathrm{EU}$, the ASEAN, and many others. It is more important not the existence of competitiveness, but the tendencies, prevailing in the activity of the organization and its members, which are either an aspiration to ensure common interests or the struggle for individual or group benefit. There are two alternatives, either the SCO space will regionalize and become a zone of co-development and collective security or the behavior of its members will be affected by egoistical spirit. But there is no definite answer yet. The activity of the SCO is influenced by non-coincidence in declared principles of cooperation both in the frames of the SCO itself and with outer states and organizations and by the practice of these principles' realization. For example, the SCO has declared openness and readiness to the cooperation with all states and international organizations, but it doesn't have any contacts with the USA and NATO. The Central Asian region solves its problems, including Afghanistan problem, separately, not in the frames of the SCO. This situation alarms both Russia and China. In turn, bilateral Russian - American and Chinese - American consultations on the issues of regional security cause suspicion in Central Asian states. In spite of this, the Central Asian countries understand that their interests are maximized when bigger powers are drawn into the region and the balancing of power between these larger entities prevents hegemony from taking place.

"Moreover, with more powers being drawn into Central Asia, they will be forced to make concessions, of which Central Asia would be the biggest silent winner. Of course all of this is still dependent on the domestic policies and stability of the individual Cen-

Paradigmata poznání. 2. 2017 
tral Asian states but in terms of foreign policy gains, this seems to be true so far" [9].

The SCO gives opportunity to the Central Asian countries to benefit from the significant success in coordination of efforts of the member states in maintaining of regional security: military cooperation, conduct of multilateral antiterrorist trainings and effective activity of Regional Counter-Terrorism Structure, mutual struggle with drug problems. But its insufficient effectiveness of responses to the region's threats, not fully formed mechanisms of the SCO, which exist for coordination of economic projects of member states, for struggle with terrorism, suppression of drug trafficking and liquidation of natural disasters' consequences may negatively affect on the regionalization processes in the Central Asia and the SCO space.

For today the members of the organization don't have one common perception of the regionalization of the SCO space. Though the members of the SCO don't have serious political disagreements, there are factors, which hinder the successful development. There is no cultural-civilization community, no stable democratic systems. The members of the SCO don't have sufficient common economic interests. Moreover, there is a fear that in case of free trade establishment in the SCO space, China will oversaturate the markets of other members with its goods. The buttress mainly on the political will of the member states led to a quick declarative institutalization, but a real effective regionalization could be achieved if there is a possibility to coordinate national interests and interests of organization. If the SCO wants to have effective regionalization, its task is to create additional spheres of cooperation, which haven't existed earlier or haven't been possible out of its frames. The fate of the organization depends on extensiveness of these spheres and its possibility to persuade the states in its capacity to achieve success.

\section{Bibliography}

1. Scheuerman, William, "Globalization", The Stanford Encyclopedia of Philosophy (Summer 2010 Edition), Edward N. Zalta (ed.), [Online] available from: http://plato.stanford.edu/archives/sum2010/entries /globalization/ (accessed 5 May 2011)

2. The Shanghai Cooperation Organization. Brief introduction to the Shanghai Cooperation Organisation. [Online] available from: http://www.sectsco.org/EN/brief.asp (accessed 6 May 2011)

3. Kerr, D. Central Asian and Russian perspectives on China's strategic emergence. International Affairs, 2010

4. Xinning Song. Bilateralism and Multilateralism in Chinese Foreign Policy in "States, Regions and the Global System - Europe and Nothern AsiaPacific in Globalised Governance" edited by Prof. Dr. Christoph Schuck and Prof. Dr. Reimund Seidelmann, 2011, Nomos, Baden-Baden.

5. Bao I. Kitai: strategicheskie intresi v Centralnoi Azii I sotrudnichestvo so stranami regiona [China: strategic interests in Central Asia and cooperation with the countries of the region], Centralnaya Asia i Kavkaz, №5(17), 2001, p.117.

6. Shanghaiskaya organizaciya sotrudnichestva: $k$ novim rubezham razvitiya [Shanghai organization of cooperation: to the new lines of development], compiler A.F. Klimenko, 2008, Moscow.

7. Karibaev, N. Commonwealth of Independent States and Shanghai Cooperation Organization: Pro et Contra. "Mapping Integration and Regionalism in a Global World: The EU and regional governance outside the EU", 3rd Annual Meeting of the GARNET network, Sciences Po Bordeaux, University of Bordeaux, 17-19 September 2008.

8. Katz, M. Russia and the Shanghai Cooperation Organization: Moscow's Lonely Road from Bishkek to Dushanbe. Asian Perspective, Vol. 32, No. 3, 2008, pp. 183-187. [Online] Available at: http://www.asianperspective.org/articles/v32n3h.pdf (Accessed 10 May 2011).

9. Neweurasia.net. SCO: Was Central Asia heard? (16 June 2009) [Online] available from: http://www.neweurasia.net/cross-regional-andblogosphere/sco-was-central-asia-heard/ (Accessed 13 May 2011).

(C) Taukebayeva E. S., Baidibekova L. A., Begim A. B., 2017. 